\title{
TOOL FOR QUALITY CONTROL OF LUBRICANTS
}

\author{
Vladimir Gryazin, Ildar Bagautdinov, Konstantin Kozlov, Vladimir Belogusev \\ Volga State University of Technology, Russia \\ vladimirgryazin@yandex.ru, bagaeldar@yandex.ru, konstantin.k-e@yandex.ru, \\ vladimir.belogusev@yandex.ru
}

\begin{abstract}
At the moment, maintenance of machinery and equipment, including agricultural ones, is carried out in accordance with the recommended frequency. However, unsteady working conditions, such as frequent starts and stops of engines, changes in temperatures and etc., require the adjustment of the frequency of maintenance. In this situation, it becomes necessary to carry out maintenance of equipment at decrease in its performance, which is largely influenced by the state of lubricating fluids. The change in their properties determines both the current state of the unit and the possible deterioration associated with the accidental ingress of contaminants into the lubricant. The purpose of the study is to intensify the use of modern information technologies in the repairs and operation of machinery through rapid assessment of changes in the quality of liquid lubricants. The developed original design of the universal sensor for quality control of lubricants allows applying it in existing units of vehicles without additional modernization. The scheme of the proposed design differs from the one of similar devices in the ability to work with industrial, motor, transmission oils and hydraulic fluid. The performed calculations and the full-scale experiment proved the operability of the proposed device. In the course of the research, the operating temperature range of the lubricating fluid was determined for the most effective diagnostics; generalized data were obtained allowing deriving the dependencies of the sensor design parameters on the temperature of the lubricant. In further research to improve the safety of the device and prevent the deterioration of the lubricating fluid in the course of incorrect operation, it is planned to improve the developed product for monitoring and informing the operator about the current state of the lubrication system, taking into account changes in operating conditions of machines and equipment.
\end{abstract}

Keywords: debugging, assembly plant, induction unit, viscosity.

\section{Introduction}

As it is known, the field of application of lubricants is wide enough - from lubrication of friction parts of tractors and cars to lubrication of agricultural rigs and hydraulic drives [1-4]. As for internal combustion engines and transmission units of agricultural machinery, liquid oils of predominantly petroleum origin, synthetic oils, grease and solids (graphite, molybdenum disulphide, polymers with fillers) are used as lubricants. In this case, the technical condition of the unit and the condition of the lubricant are interrelated - the wear products contaminate the lubricants, and the dirt that gets into the lubrication system, in turn, reduces the performance of the machine $[1 ; 5-8]$. Thus, the possibility of monitoring the condition of lubricants during the operation of the machine will allow increasing the reliability of units and reducing the cost of repairs and maintenance.

The relevance of the application of quality control sensors for lubricants is associated with a high probability of changing the lubricant parameters as a result of natural aging, oxidation, and contamination by foreign inclusions [9-11].

The purpose of this paper is to ensure the possibility of using modern information technologies in the repair and maintenance of equipment by developing a universal sensor for quality control of lubricants that will allow it to be used in existing units of vehicles without additional modernization of the latter and to carry out rapid diagnosis of changes in the quality of liquid lubricants.

The objectives of this study are the following:

- development of the design of the universal sensor for quality control of lubricants (hereinafter referred to as the sensor), and its debugging for operation in units of modern vehicles;

- development of a diagnostic and indication module with the possibility of its connection to diagnostic systems of vehicles;

- development of a sensor prototype and verification of its operability.

\section{Materials and methods}

Figure 1 presents a scheme of a universal sensor for quality control of lubricants. 


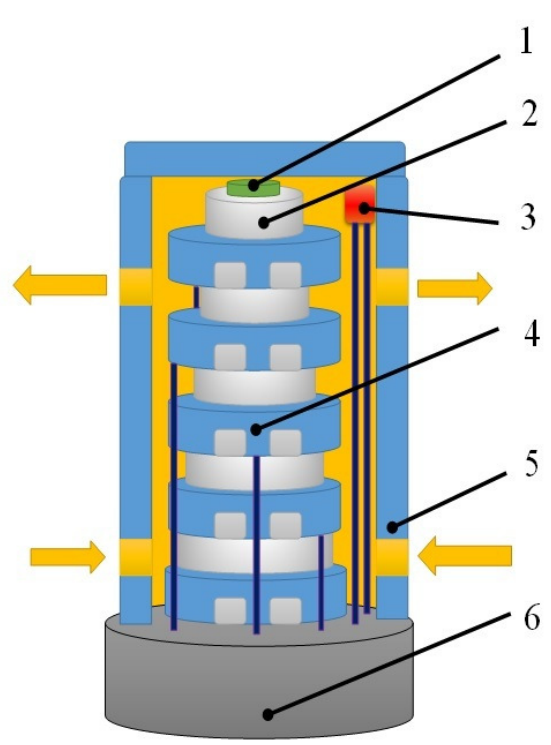

a)

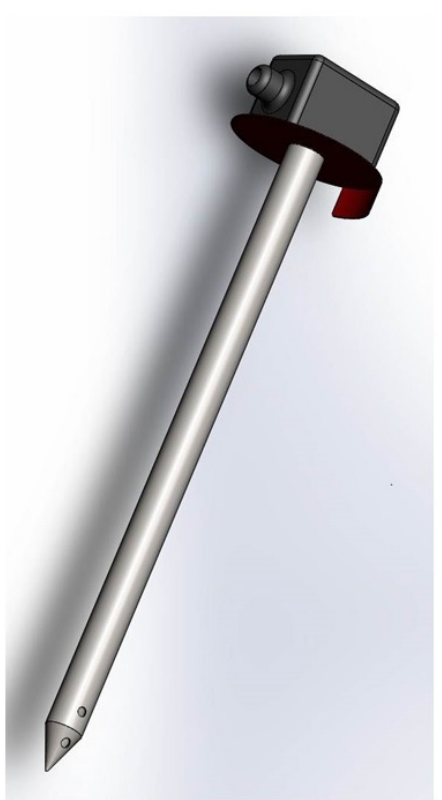

b)

Fig. 1. Universal sensor for quality control of lubricants (a) scheme and (b) external view: 1 - central rod; 2 - capacitor plate; 3 - temperature sensor; 4 - dielectric washer; 5 - protective casing; 6 - base

The design of the sensor is protected by the Russian Federation patent No. 164115 "Device for express control of the dielectric strength".

The functional scheme of operation is presented in Figure 2.

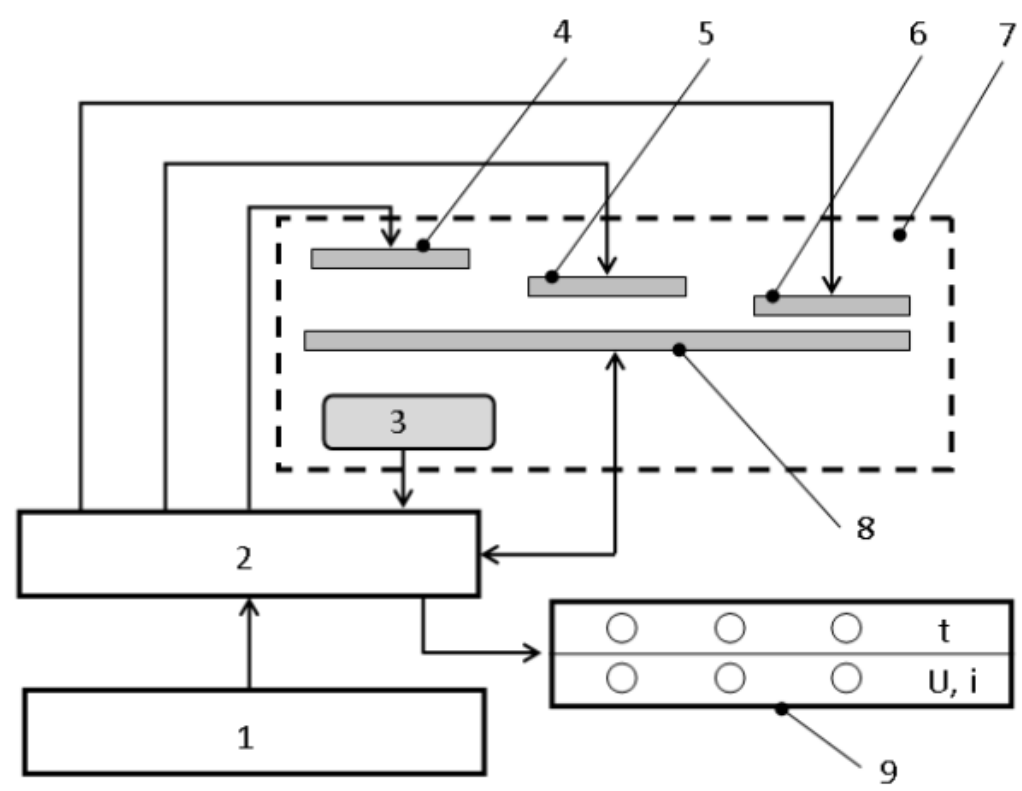

Fig. 2. Functional scheme of operation of sensor for quality control of lubricants: 1 - step-up transformer; 2 - controller; 3 - temperature sensor; 4,5 , and 6 - plates of the capacitor; 7-test cell; 8 - central rode; 9 - indicator

The principle of operation of a universal sensor for quality control of lubricants is as follows.

The interelectrode gap of each plate of the capacitor 4, 5, and 6 of the test cell 7 is pre-calibrated to a predetermined breakdown voltage $U$ depending on the temperature and the type of a dielectric. As a result, the dependences of the sought value of the electric strength $E$ of the "clean" dielectric on the temperature $t$ and the breakdown voltage $U$ for each interelectrode gap are obtained. Since at a given temperature the electrical strength is linearly dependent on the breakdown voltage and the value of the 
interelectrode gap, it is possible to control the value of the breakdown voltage from the "pure" value to a smaller one in order to determine the permissible level of contamination of the investigated dielectric. For example, for an acceptable $20 \%$ deviation from the "pure" value, it is necessary to reduce the breakdown voltage at each interelectrode gap by $20 \%$. In this case, the breakdown of the interelectrode gap will indicate the achievement and/or excess of the level of contamination of the investigated dielectric.

The values of the breakdown voltage are regulated by the step-up transformer 1 and the control circuit 2.

In the test cell 7, a dielectric is placed so that the plates of the capacitor are completely submerged. The step-up transformer 1 converts the voltage of the power supply system (not shown in Fig. 2) into a breakdown voltage and supplies it to the control circuit 2 . The control circuit 2, based on the temperature sensor 3 and the calibration data, supplies a breakdown voltage to a certain plate 4,5 or 6 of the test cell 7. The choice of a plate is determined by the actual temperature of the dielectric.

If the dielectric under investigation turns out to be contaminated more greatly than determined by the initial calibration, a breakdown occurs in the interelectrode space of test cell 7 . Accordingly, a breakdown voltage appears on the central rod 8, which is registered by the control circuit 2 and displayed on the indicator 9. After registering the breakdown voltage, the control circuit 2 interrupts the supply of voltage.

If the degree of contamination of the dielectric is within acceptable limits, a breakdown does not occur. In this case, the operation of the system is monitored by the operator based on the readout of the temperature sensor 3 .

This principle of operation is explained by the fact that at different temperatures of a dielectric (lubricating fluid) its electrical strength varies, therefore, either the breakdown voltage or the gap between the capacitor plate and the central rod must change. Structurally, we provide the constant value of the breakdown voltage, and the gap is provided beforehand by the accurate manufacture of each of the plates and the exact position of the plate relative to the central rod.

If the lubricating fluid is pure, then breakdown does not occur. If, however, the quality and/or composition of the lubricating fluid at a given temperature do not meet the requirements, then breakdown will occur. Further determination of the quality of the lubricating fluid is impractical, since with the increase of the temperature of the lubricating fluid its electrical strength decreases and the breakdown will occur continuously. To prevent the sensor from failing, the controller stops checking for a breakdown, however, the temperature of the lubricating fluid is still displayed.

\section{Results and discussion}

Preliminary calculations of design parameters of the sensor based on the reference values of the electric strength of the oil have shown that the most optimal breakdown voltage is up to $1000 \mathrm{~V}$ with a gap value of $0.2 \mathrm{~mm}$. With this voltage, it is possible to provide gaps between the central rod and the rods of the capacitors without significantly increasing the cost of the structure.

To estimate the effectiveness of the device assembled, experimental studies of pure and used oils I-20A at various temperatures were carried out. The obtained values of the breakdown voltage are presented in Table 1.

Table 1

Breakdown voltage values

\begin{tabular}{|c|c|c|c|c|c|c|}
\hline \multirow[b]{2}{*}{$t$} & \multicolumn{2}{|c|}{ Pure oil } & \multicolumn{2}{|c|}{ Used oil } & \multirow{2}{*}{$\begin{array}{c}\text { Difference } \\
\text { between } \\
\text { obtained values }\end{array}$} & \multirow{2}{*}{ Dispersion } \\
\hline & Min & Max & Min & Max & & \\
\hline${ }^{\circ} \mathrm{C}$ & $\mathrm{V}$ & $\overline{\mathrm{V}}$ & $\bar{V}$ & $\overline{\mathrm{V}}$ & $\overline{\mathrm{V}}$ & $\%$ \\
\hline 0 & 508 & 529 & 536 & 553 & 7 & 1.31 \\
\hline 20 & 510 & 525 & 514 & 573 & -11 & -2.14 \\
\hline 40 & 501 & 512 & 531 & 571 & 19 & 3.58 \\
\hline 60 & 507 & 524 & 579 & 599 & 55 & 9.50 \\
\hline 80 & 507 & 524 & 567 & 631 & 43 & 7.58 \\
\hline
\end{tabular}


For each temperature value, the minimum and maximum values of the breakdown voltage were obtained.

According to the obtained results, we can conclude that the most effective range of temperatures to diagnose the condition of the lubricating fluid is from 60 to $80^{\circ} \mathrm{C}$.

When using specific indicators, for example, the ratio between the value of breakdown voltage and temperature, Kelvin should be used as a measurement unit.

The histogram of the distribution of the specific breakdown voltage (Volts per Kelvin) is shown in Figure 3.

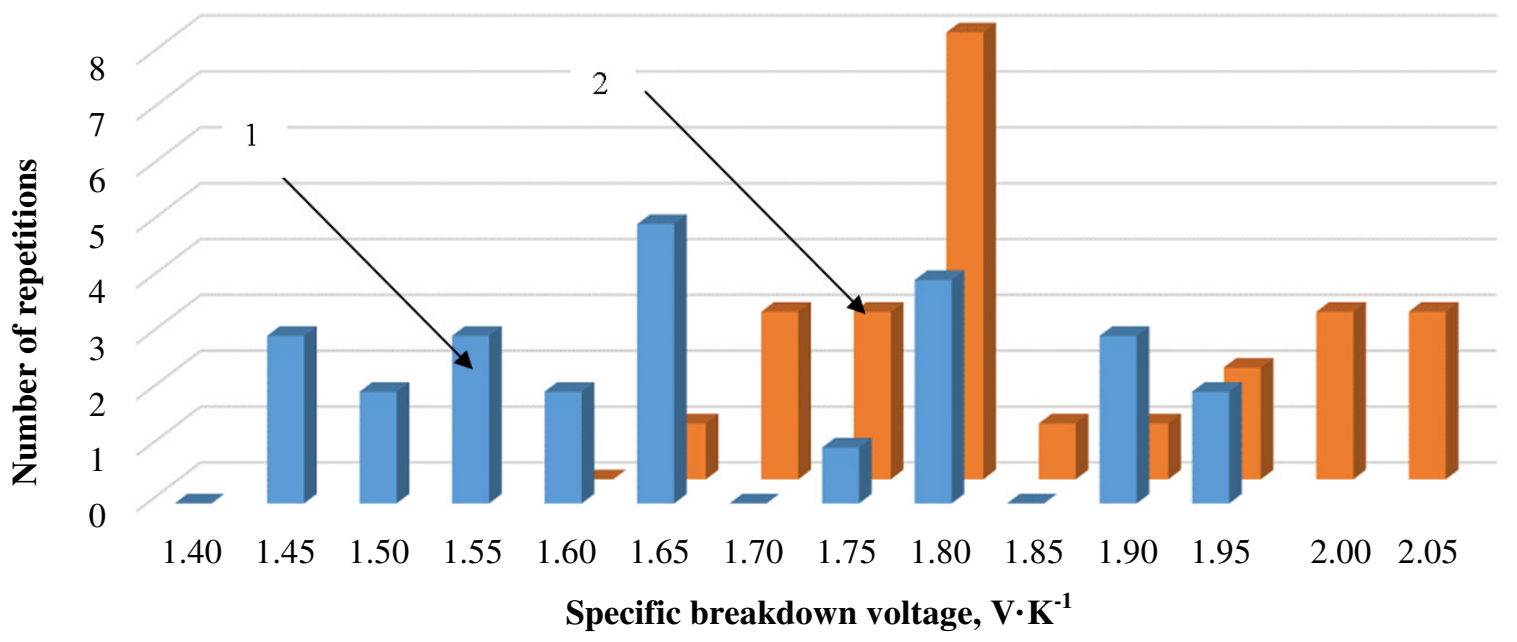

Fig. 3. Histogram of distribution of specific breakdown voltage: 1 - for pure oil; 2 - for used oil

As shown by the full-scale experiment, for the used oil, the field of distribution of the specific breakdown voltage shifts towards higher values. The maximum number of repetitions for the used oil (8 units) was $1.8 \mathrm{~V} \cdot \mathrm{K}^{-1}$, which exceeds the amount of repetition (4 units) for the pure one.

Zero values of the specific breakdown voltage of pure oil at values from 2 to $2.05 \mathrm{~V} \cdot \mathrm{K}^{-1}$ unequivocally show that in this area no breakdown will occur. The presence of breakdown in this range will give a clear indication of the lubricating fluid as contaminated, and, as a consequence, the sensor should be designed for work in this range.

\section{Conclusions}

In this paper, a universal sensor for the quality control of lubricants has been developed, which makes it possible to use it in existing units of vehicles without additional modernization of the latter. The scheme of the proposed design differs from similar devices (for example, oil quality control of internal combustion engines) by its ability to work with industrial, transmission oils and hydraulic fluid.

The use of a universal sensor for the quality control of lubricants provides continuous monitoring of their state in terms of viscosity, temperature, moisture and oxidation. The developed design of the universal sensor will ensure the implementation of early measures to detect and prevent the failure of units of vehicle transmissions. With the help of the proposed device, the concept of operating machines according to their actual state can be realized, and not only by mileage or service life as in most modern vehicles. This condition allows the most efficient use of lubricating fluids, as well as reduces operating costs.

\section{References}

[1] Hutchings I., Shipway P. Lubricants and lubrication. Tribology (Second Edition). Friction and Wear of Engineering Materials. Oxford: Butterworth-Heinemann, 2017. 412 p.

[2] Jafari A.J., Hassanpour M. Analysis and comparison of used lubricants, regenerative technologies in the world. Resources, Conservation and Recycling, vol. 103, 2015, pp. 179-191. 
[3] Зиганшина А.В., Зиганшин Р.А. Анализ показателей свойств масел автомобильных трансмиссий (Analysis of the properties of the oils for automobile transmissions). Russian journal of science prospects: Перспективы науки, 2014, No 5 (56), pp. 45-47. (In Russian).

[4] Максименко А.Н., Бездников Д.В., Кутузов В.В., и др. Влияние качества рабочей жидкости на работоспособность гидропривода (Influence of quality of a working liquid on working capacity of a hydraulic drive). Russian journal Lorry: Грузовик, 2007, No 7, pp. 26-28. (In Russian).

[5] Барышев В.И., Лайко К.К., Анищенко П.В. Критерии прочности рабочих жидкостей (Criteria for strength of working fluids). Russian bulletin of the Perm National Research Polytechnic University. Aerospace Engineering: Вестник Пермского национального исследовательского политехнического университета. Аэрокосмическая техника, 2013, № 35, pp. 64-82. (In Russian).

[6] Коваленко В.П., Улюкина Е.А., Липаева М.А. Обеспечение чистоты топлив и масел при эксплуатации сельскохозяйственной техники (Maintenance of pureness of fuels and oils at operation of agricultural machinery). Russian bulletin of the Federal State Educational Institution of Higher Professional Education Moscow State Agroengineering University named after. V.P. Goryachkina: Вестник Федерального государственного образовательного учреждения высшего профессионального образования Московский государственный агроинженерный университет им. В.П. Горячкина, 2015, № 3, pp. 44-50. (In Russian).

[7] Пильгунов В.Н. Исследование разрывной прочности минерального масла (Research of the Strength of Mineral Oil). Science and Education: a scientific edition of the MSTU. N.E. Bauman: Наука и образование: научное издание МГТУ им. Н.Э. Баумана, 2012, № 5. (In Russian).

[8] Поп Г.С., Шабо М.Д., Кучеровский В.М. Смазочные материалы из растительных масел (Lubricants from vegetable oils). Russian journal of oil, gas and business: Нефть, газ и бизнес, 2007, No 4, pp. 19-24. (In Russian).

[9] Kozlov K.E., Egorov A.V., Belogusev V.N. Experimental Evaluation of Chain Transmissions Lubricants Quality Using a New Method Based on Additional Inertia Moment Use. Procedia Engineering, vol. 206, 2017, pp. 617-623.

[10] Pinheiro C.T., Pais R.F., Ferreira A.G.M. etc. Measurement and correlation of thermophysical properties of waste lubricant oil. The Journal of Chemical Thermodynamics, vol. 116, 2018, pp. 137-146.

[11]Zamora D., Blanco M., Bautista M. etc. An analytical method for lubricant quality control by NIR spectroscopy. Talanta, vol. 89, 2012, pp. 478-483. 